\title{
Correction to: Challenges in small-molecule target identification: a commentary on "BDA-366, a putative Bcl-2 BH4 domain antagonist, induces apoptosis independently of $\mathrm{BCl}-2$ in a variety of cancer cell models"
}

\author{
Richard W. Birkinshaw
}

Published online: 3 March 2021

(c) The Author(s), under exclusive licence to ADMC Associazione Differenziamento e Morte Cellulare 2021

Correction to: Cell Death \& Differentiation

https://doi.org/10.1038/s41418-020-00717-4

Published: 19 January 2021

The original version of this article unfortunately contained a mistake. It should have included a reference to another article in Cell Death \& Disease. The author has asked to add the reference to the start of paragraph 3, first sentence: In this issue of Cell Death and Disease, Vervloessem et al. [8] have convincingly challenged the original hypothesis that BDA-366 targets BCL2. This also results in the renumbering of references 8-14. The added reference is: Vervloessem T, Sasi B.K., Xerxa E, Karamanou S, Kale J, La Rovere R.M. et al. BDA-366, a putative Bcl-2 BH4 domain antagonist, induces apoptosis independently of $\mathrm{Bcl}-2$ in a variety of cancer cell models. Cell Death Dis. 2020;11:769. The original article has been corrected. 